\title{
Research on the Coordination between Economy and Human Ecological Settlement Environment
}

\author{
Jingyi Zhang, Liying Zhang, Yang Zhang*, Chengliang Wu \\ School of Economics and Management Beijing Forestry University, Beijing, China
}

Received: 7 May 2021

Accepted: 2 July 2021

\begin{abstract}
Human ecological settlement environment gradually attracts attention due to the development of economy and urbanization. The development of human ecological settlement environment and the economy in the Yellow River Basin of China are in a relationship of mutual influences and constraints, so their coordinated development is of great importance. We evaluated the development index and coupling coordination among ecological environment, economy, and the residential environment in the Yellow River basin and analyzed the coordinated relationship. Based on the empirical analysis, we concluded that the overall ecological environment in the Yellow River Basin is relatively well developed, and the economic development is relatively backward, and the residential environment is stable, with the development trend in the upper reaches slightly better than that in the middle and lower reaches. The overall coupling coordination in the Yellow River Basin is at the primary level, with a "W" pattern, and the regions are characterized by rising in the upper reaches, stable in the middle reaches, and falling in the lower reaches in terms of the development trend. Therefore, seizing the development opportunities, realizing regional joint and differentiated development, and insisting on the priority development of ecological environment will promote the coordinated development of human ecological settlement environment and economy in the Yellow River Basin of China.
\end{abstract}

Keywords: human ecological settlement environment, economy, the Yellow River Basin of China

\section{Introduction}

As socialism with Chinese characteristics enters a new era, people have a growing demand for a better life. There occurs much closer combination of economy and human ecological settlement environment. After the reform and opening up, China is going through the accelerated urbanization and economic development,

*e-mail: yangzhang@bjfu.edu.cn with high emissions and consumption coming into being. The rapid urbanization has been developed at the cost of the damage of human ecological settlement environment, especially in the Yellow River Basin, an ecologically fragile area. In order to face the challenges of human ecological settlement environment in the Yellow River Basin and achieve sustainable development, it is necessary to realize the coordinated development between human ecological settlement environment and economic development. Therefore, the coupling coordination among ecological environment, economic development and residential environment are 
explored in this paper in the background of ecological protection and high-quality development in the Yellow River Basin so as to grasp the law among the three aspects, eventually to achieve the coordinated and sustainable development of the three aspects.

\section{Literature Review}

There is a lot of research literatures on the relationship between human ecological settlement environment and economy with the focus on the impact of economy on human ecological settlement environment and the relationship between economy and ecological environment. The development of the human ecological settlement environment cannot be separated from the economy, which is not only an important factor affecting the human ecological settlement environment, but also an important factor leading to the differences of the human ecological settlement environment in different regions [1-2]. The ecological environment influences the living environment of the city and then the human ecological settlement environment [3]. It can be seen that both ecological environment and economy are important factors affecting the human ecological settlements environment. There is also a correlation between them, Grossman and Krueger (1991) put forward the Kuznetz curve, believing that the relationship between economic growth and environmental pollution presents an inverted " $U$ " shape [4]. Later, many scholars used different methods to verify this conclusion in different regions [5-11]. Therefore, the coordinated development of economy and ecological environment is of vital importance and an inevitable requirement for sustainable urban development. A good ecological environment can promote the development of local economy, and otherwise inhibit the development [12-16]. However, many scholars have studied the coupled and coordinated development level of economic and ecological environment in some Chinese cities
[17-23], and proposed that the ecological environment and economic development are unbalanced and the ecological environment development lags behind the economic development level [24-26].

\section{Overview of the Study Area}

The Yellow River is the most important cradle of Chinese civilization, and the Chinese call it "mother river". The Yellow River basin is located in northern China, 32 $\sim 42^{\circ}$ north latitude, $96^{\circ} \sim 119^{\circ}$ east longitude. It is originated in the Yoguzongli basin, the northern foothills of the Bayankara Mountains on Tibetan Plateau, flowing through 9 provinces, Qinghai, Sichuan, Gansu, Ningxia, Inner Mongolia, Shaanxi, Shanxi, Henan, Shandong, and finally injected into the Bohai Sea in Shandong province. The Yellow River flows from its source to Hekou Town in Hohhot City, Inner Mongolia as the upper reaches of the Yellow River, with a river length of $3472 \mathrm{~km}$ and a watershed area of 428,000 square kilometers. Its middle reaches are from Hekou Town to Tahuayu in Zhengzhou City, Henan Province, with a river length of $1206 \mathrm{~km}$ and a watershed area of 344,000 square kilometers. And the lower reaches are from Tahuayu to its end, with a river length of $786 \mathrm{~km}$ and a watershed area of only 23,000 square kilometers (Fig. 1).

President Xi Jinping held a symposium on ecological protection and high-quality development of the Yellow River Basin in Zhengzhou on September 18, 2019. It was mentioned that ecological protection and high-quality development of the Yellow River Basin was a major national strategy, that the Yellow River Basin was an important ecological barrier and an important economic zone in China, and that the protection of the Yellow River was a thousand-year plan for the great rejuvenation and sustainable development of the Chinese nation. In January 2020, the sixth session of the Central Finance and Economics Commission further emphasized that

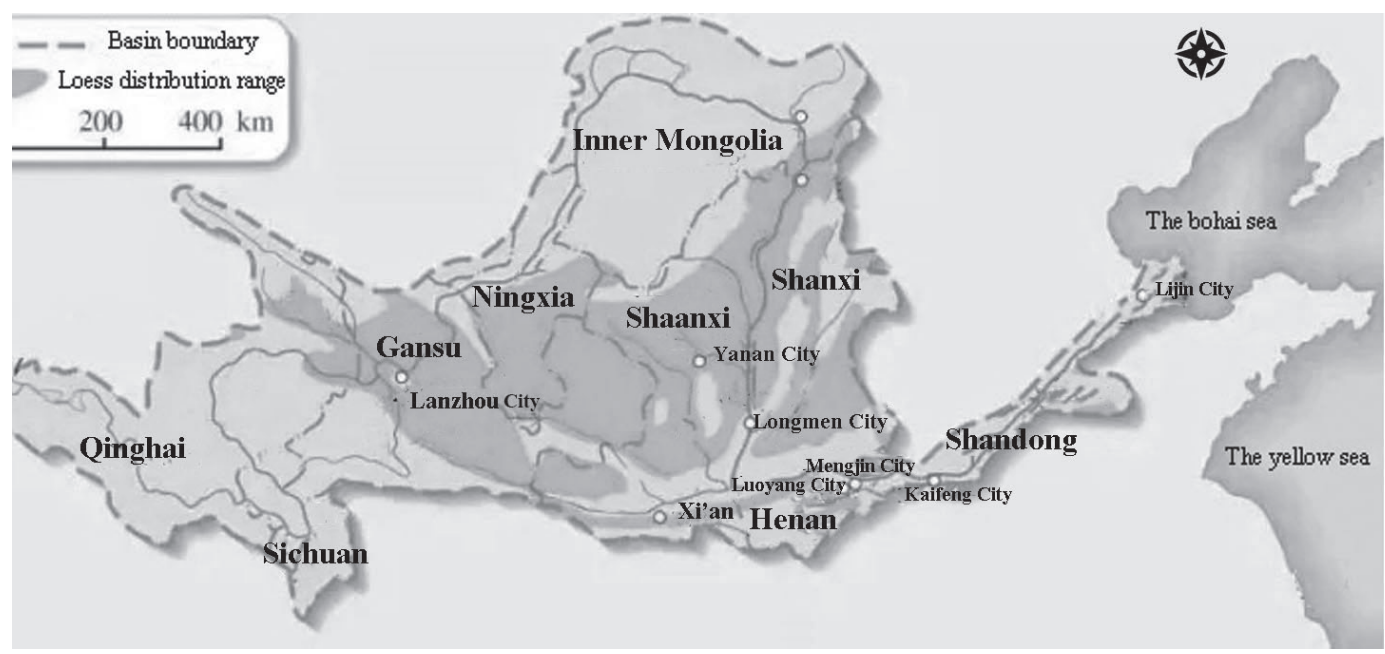

Fig. 1. Schematic Diagram of Yellow River Basin. 
the intensified protection and governance for the Yellow River basin should take the path of ecological protection and high-quality development. Therefore, it is necessary to further promote the growth of the economy and the improvement of residential environment under the requirements of ecological protection and high-quality development of the Yellow River and to promote their coordinated development. High-quality development is that the production, structure and dynamics can better meet the growing demands of the people. Therefore, development in the integrated, balanced and coordinated way in the whole area is the strategy to be followed in the high-quality development of the Yellow River basin [27].

\section{Methods}

The empirical analysis was made in this paper to evaluate the comprehensive development of the economy, ecological and residential environment in the Yellow River Basin. Firstly, the range method was used to dimensionless process the crude oil data of the index system in order to facilitate the comprehensive evaluation of each index. Secondly, the entropy method was used to score the economic development system, ecological environment system and residential environment system. Finally, the coupling coordination model was used to empirically analyze the coupling relationship among the three systems.

The Entropy Method

$$
\begin{aligned}
& X_{i j}=\frac{x_{i j}-x_{\min }}{x_{\max }-x_{\min }} \\
& X_{i j}=\frac{x_{\max }-x_{i j}}{x_{\max }-x_{\min }}
\end{aligned}
$$

For the forward data, Equation (1) was used for standardization. And for the inverse data, Equation (2) was used for standardization. $x_{i j}$ is the original value of the $j$ th indicator in year $i ; X_{i j}$ is the value of the $j$ th indicator in year $i$ after standardization; $x_{\max }$ and $x_{\text {min }}$ denote the maximum and minimum values of the indicator respectively. In order to make the data operation meaningful, the zero value must be eliminated. So, the overall translation of the nondimensionalized data was performed: $X_{i j}=X_{i j}+\alpha$. In order not to destroy the law of the original data, the value of $\alpha$ should be as small as possible, $\alpha=0.0001$.

The equation was used to calculate the weight of municipality $i$ under the $j$ th indicator, as shown in the following.

$$
P_{i j}=\frac{X_{i j}}{\sum_{i=1}^{m} X_{i j}}(j=1,2,3 \ldots n)
$$

The equation was used to calculate the entropy value of the jth indicator, as shown in the following.

$$
e_{j}=-k * \sum_{i=1}^{m} P_{i j} \ln P_{i j}
$$

$k=\frac{1}{\ln m}, e_{j} \in[0,1]_{\text {in this equation. }}$

The equation was used to calculate coefficient of variation of the jth indicator, as shown in the following.

$$
d_{j}=1-e_{j}
$$

The equation was used to calculate the index weights, as shown in the following.

$$
W_{j}=\frac{d_{j}}{\sum_{j=1}^{n} d_{j}}
$$

The equation was used to calculate the evaluation index of the jth indicator.

$$
S_{i}=\sum_{j=1}^{n} W_{j} * X_{i j}(i=1,2,3 \ldots m)
$$

\section{The Coupling Coordination Model}

Since three subsystems of ecological environment, economic development and residential environment were involved in this paper, so $\mathrm{n}=3$, the coupling coordination degree function is

$$
C=\sqrt[3]{\frac{f(x) \times g(y) \times h(z)}{\left[\frac{f(x)+g(y)+h(z)}{3}\right]^{3}}}
$$

In this equation, $f(x), g(y)$, and $h(z)$ represent the development indexes obtained by weighting the standardized values of indicators of three systems: ecological environment, economic development and residential environment in the Yellow River basin respectively. $\mathrm{C}$ is the coupling degree of the three systems $(0 \leq \mathrm{C} \leq 1)$. The closer $\mathrm{C}$ is to 1 , the higher coupling degree is among the systems. And the closer $\mathrm{C}$ is to 0 , the lower coupling degree is among the systems.

$$
\begin{gathered}
D=\sqrt{T \times C} \\
T=\alpha f(x)+\beta g(y)+\gamma h(z)
\end{gathered}
$$

In this equation, $\mathrm{C}$ is the coupling degree, and $\mathrm{D}$ is the coupling coordination degree, and $\mathrm{T}$ is the comprehensive evaluation index of the coupling coordination degree. And $\alpha, \beta$ and $\gamma$ are the weights of each subsystem respectively. It is believed that the three systems of ecological environment, economic growth and residential environment are equally important, so $\alpha$, $\beta$ and $\gamma$ are taken as $1 / 3$. 
Table 1. The classification standard of coupling coordination degree.

\begin{tabular}{|c|c|c|c|}
\hline The coupling coordination & Level & The coupling coordination & Level \\
\hline $0 \leq D<0.1$ & Extreme imbalance & $0.5 \leq D<0.6$ & Slight coordination \\
\hline $0.1 \leq D<0.2$ & Severe imbalance & $0.6 \leq D<0.7$ & Primary coordination \\
\hline $0.2 \leq D<0.3$ & Inter mediate imbalance & $0.7 \leq D<0.8$ & Intermediate coordination \\
\hline $0.3 \leq D<0.4$ & Slight imbalance & $0.8 \leq D<0.9$ & Healthy coordination \\
\hline $0.4 \leq D<0.5$ & On the verge of imbalance & $0.9 \leq D<1$ & High-quality coordination \\
\hline
\end{tabular}

The coupling coordination of the three systems in this study was between 0.6 and 0.8 from 2014 to 2018 after calculation. The grade classification criteria of the coupling coordination degree are shown in Table 1.

\section{Index System}

Based on the connotation of the three systems of ecological environment, economic development and residential environment, an evaluation index system for the three systems of ecological environment, economic development and residential environment has been constructed in this paper based on the principles of systematicity, operability and objectivity. Besides, the literatures on high-quality development and residential environment in the Yellow River Basin has been referred to construct the evaluation index system of the three systems as shown in Table 2.

Table 2. Evaluation of index system of ecological environment, economic development and residential environment in the Yellow River Basin.

\begin{tabular}{|c|c|c|c|c|}
\hline Indicator I & Indicator II & Indicator III & Units & Attributes \\
\hline \multirow{7}{*}{$\begin{array}{l}\text { Ecological environ- } \\
\text { ment (El) }\end{array}$} & \multirow{2}{*}{ The air $\left(E l_{1}\right)$} & Sulfur dioxide emissions $\left(\mathrm{El}_{11}\right)$ & Million tons & - \\
\hline & & Smoke(power) dust emissions $\left(\mathrm{El}_{12}\right)$ & Million tons & - \\
\hline & \multirow{2}{*}{$\begin{array}{l}\text { Landscaping } \\
\qquad\left(\mathrm{El}_{2}\right)\end{array}$} & Greenery coverage $\left(\mathrm{El}_{21}\right)$ & Percentage & + \\
\hline & & Park area per capita $\left(\mathrm{El}_{22}\right)$ & Square meter/capita & + \\
\hline & The water $\left(\mathrm{El}_{3}\right)$ & Urban sewage treatment $\left(\mathrm{El}_{31}\right)$ & Percentage & + \\
\hline & \multirow[b]{2}{*}{ Others $\left(\mathrm{El}_{4}\right)$} & Domestic garbage harmless $\left(\mathrm{El}_{41}\right)$ & Percentage & + \\
\hline & & Areas for road cleaning $\left(\mathrm{El}_{42}\right)$ & $\begin{array}{l}\text { Square million meters/ } \\
\text { capita }\end{array}$ & + \\
\hline \multirow{7}{*}{$\begin{array}{l}\text { Economic develop- } \\
\text { ment (En) }\end{array}$} & \multirow{2}{*}{ Size $\left(\operatorname{En}_{1}\right)$} & General revenue for public budget $\left(\mathrm{En}_{11}\right)$ & Hundred million RMB & + \\
\hline & & GDP per capita $\left(\mathrm{En}_{12}\right)$ & RMB & + \\
\hline & \multirow{2}{*}{ Structure $\left(\mathrm{En}_{2}\right)$} & Percentage of secondary industry $\left(\mathrm{En}_{21}\right)$ & Percentage & + \\
\hline & & Percentage of tertiary industry $\left(\mathrm{En}_{22}\right)$ & Percentage & + \\
\hline & \multirow{3}{*}{ Benefits (En3) } & Disposable income $\left(\mathrm{En}_{31}\right)$ & RMB & + \\
\hline & & Household consumption( $\left(\mathrm{En}_{32}\right)$ & RMB & + \\
\hline & & Reregistered urban unemployment rate $\left(\mathrm{En}_{33}\right)$ & Percentage & - \\
\hline \multirow{7}{*}{$\begin{array}{l}\text { Residential environ- } \\
\text { ment }(\mathrm{R})\end{array}$} & \multirow{3}{*}{$\begin{array}{l}\text { Infrastructure } \\
\qquad\left(\mathrm{R}_{1}\right)\end{array}$} & Urban latrines $\left(\mathrm{R}_{11}\right)$ & Amount & + \\
\hline & & City public water supply $\left(\mathrm{R}_{12}\right)$ & Percentage & + \\
\hline & & City gas supply $\left(\mathrm{R}_{13}\right)$ & Percentage & + \\
\hline & \multirow{3}{*}{$\begin{array}{l}\text { Public services } \\
\qquad\left(\mathrm{R}_{2}\right)\end{array}$} & Health organizations per ten thousand $\left(\mathrm{R}_{21}\right)$ & Amount & + \\
\hline & & $\begin{array}{l}\text { The proportion of education outcome in public } \\
\text { expenditure }\left(\mathrm{R}_{22}\right)\end{array}$ & Percentage & + \\
\hline & & Public libraries $\left(\mathrm{R}_{23}\right)$ & Amount & + \\
\hline & Houses $\left(\mathrm{R}_{3}\right)$ & Per capita dwelling space of urban residents $\left(\mathrm{R}_{31}\right)$ & Square meter/capita & + \\
\hline
\end{tabular}


Table 3. Descriptive statistical characteristics of three annual indicators.

\begin{tabular}{|c|c|c|c|c|c|c|c|c|c|c|c|c|}
\hline \multirow{2}{*}{ Indicator } & \multicolumn{4}{|c|}{2018} & \multicolumn{4}{|c|}{2016} & \multicolumn{4}{|c|}{2014} \\
\hline & Means & Max & Min & Std & Means & Max & Min & Std & Means & Max & Min & Std \\
\hline $\mathrm{El}_{11}$ & 2.77 & 9.62 & 0.26 & 2.27 & 5.19 & 17.17 & 0.78 & 3.62 & 9.68 & 23.51 & 1.63 & 4.66 \\
\hline $\mathrm{El}_{12}$ & 1.94 & 13.90 & 0.12 & 2.37 & 4.01 & 10.06 & 0.50 & 2.46 & 7.20 & 25.40 & 0.84 & 4.91 \\
\hline $\mathrm{El}_{21}$ & 39.91 & 45.22 & 24.41 & 3.86 & 39.33 & 45.11 & 17.27 & 5.47 & 39.51 & 46.86 & 24.55 & 4.55 \\
\hline $\mathrm{El}_{22}$ & 16.51 & 37.09 & 8.03 & 6.15 & 15.72 & 33.84 & 5.78 & 6.04 & 15.16 & 37.45 & 4.65 & 6.07 \\
\hline $\mathrm{El}_{31}$ & 96.47 & 100.00 & 90.41 & 2.36 & 94.26 & 99.94 & 78.05 & 3.93 & 91.97 & 99.59 & 71.39 & 6.65 \\
\hline $\mathrm{El}_{41}$ & 99.57 & 100.00 & 95.12 & 1.14 & 96.89 & 100.00 & 33.75 & 11.14 & 93.22 & 100.00 & 19.80 & 14.77 \\
\hline $\mathrm{El}_{42}$ & 2169.1 & 7877.00 & 198.00 & 1748.5 & 2064.2 & 7491.00 & 192.00 & 1649.0 & 1645.4 & 4423.00 & 80.00 & 1254.6 \\
\hline $\mathrm{En}_{11}$ & 215.66 & 1152.10 & 18.73 & 221.48 & 195.60 & 1011.20 & 17.99 & 196.10 & 175.97 & 833.88 & 17.26 & 163.26 \\
\hline $\mathrm{En}_{12}$ & 63133 & 191942 & 16369 & 34144 & 63225 & 215488 & 22747 & 42071 & 59701 & 200152 & 21796 & 40472.5 \\
\hline $\mathrm{En}_{21}$ & 47.17 & 62.81 & 27.60 & 8.79 & 48.88 & 63.00 & 27.87 & 8.01 & 54.25 & 75.70 & 29.30 & 9.85 \\
\hline $\mathrm{En}_{22}$ & 44.17 & 68.70 & 30.90 & 8.89 & 42.58 & 68.56 & 30.90 & 8.50 & 37.27 & 66.40 & 21.90 & 9.67 \\
\hline $\mathrm{En}_{31}$ & 25393 & 41755 & 16883 & 7079.1 & 21209.6 & 35759 & 14371 & 5946 & 23932 & 56129.5 & 11532 & 9404.3 \\
\hline $\mathrm{En}_{32}$ & 17942 & 31256 & 10943 & 5326.2 & 14869 & 26872 & 9245.00 & 4488 & 15909 & 24117 & 7796 & 4696.4 \\
\hline $\mathrm{En}_{33}$ & 2.97 & 4.00 & 2.10 & 0.57 & 3.10 & 4.00 & 1.90 & 0.63 & 3.06 & 4.10 & 1.40 & 0.71 \\
\hline $\mathrm{R}_{11}$ & 433.46 & 2544.00 & 44.00 & 550.67 & 282.43 & 998.00 & 16.00 & 257.40 & 258.51 & 963.00 & 7.00 & 243.08 \\
\hline $\mathrm{R}_{12}$ & 96.01 & 100.00 & 79.64 & 5.15 & 9 & 00 & 84.94 & 3.83 & 97.53 & 100.00 & 81.24 & 3.97 \\
\hline $\mathrm{R}_{13}$ & 96.36 & 100.00 & 70.48 & 6.23 & 94.36 & 100.00 & 61.90 & 7.61 & 94.24 & 100.00 & 75.94 & 5.78 \\
\hline $\mathrm{R}_{21}$ & 7.13 & 11.75 & 2.29 & 2.30 & 7.13 & 13.99 & 2.87 & 2.64 & 7.25 & 16.13 & 2.06 & 3.06 \\
\hline $\mathrm{R}_{22}$ & 16.07 & 22.83 & 10.36 & 3.26 & 16.85 & 22.49 & 10.10 & 3.76 & 16.99 & 22.81 & 10.43 & 3.72 \\
\hline $\mathrm{R}_{23}$ & 9.46 & 17.00 & 3.00 & 3.57 & 9.31 & 17.00 & 3.00 & 3.53 & 9.29 & 17.00 & 3.00 & 3.54 \\
\hline $\mathrm{R}_{31}$ & 32.09 & 79.74 & 17.16 & 12.47 & 31.78 & 83.02 & 7.41 & 13.46 & 33.80 & 106.89 & 10.59 & 18.19 \\
\hline
\end{tabular}

In this paper, 35 prefecture-level cities in the Yellow River Basin were selected as the targets of the study. Data were obtained from the China Statistical Yearbook, China Statistical Yearbook of Urban Construction, statistical yearbooks of provinces and cities, and statistical bulletins of national economic and social development from 2014 to 2018. Since sulfur dioxide emissions and smoke (dust) emissions lacked data in 2018, the forecast was made using the trend function in Excel tables, and the remaining individual indicators had missing values, which were replaced by provincial data or provincial average data.

The data of indicators in 2014, 2016, 2018 were selected by the Stata software for descriptive statistical analysis (Table 3). The following were found: (1) Some indicators of ecological environment, economic growth and residential environment of 35 cities in the Yellow River basin varied greatly in terms of the space distribution. The maximum park green space per capita in 2018 was 37.09 square meters/person (in Erdos), while the minimum was 8.03 square meters/ person (in Haidong city). The maximum road-sweeping area was 78.77 million square meters/day (in Jinan city), the minimum was 1.98 million square meters/ day (in Haidong City). The highest GDP per capita in 2016 could be 215,488 yuan (in Ordos) and the lowest
22,747 yuan (in Xinzhou City), the highest disposable income per capita was 35,759 yuan (in Baotou City) and the lowest 14,371 yuan (in Xinzhou City). The maximum number of urban public toilets owned in 2014 was 963 (in Zhengzhou City) and the minimum 7 (in Haidong City). In addition, there were differences in space in a number of indicators such as sulfur dioxide emissions, smoke and dust emissions, general public budget expenditures, and residents' consumption expenditures. (2) In terms of temporal changes, the average values of the three negative indicators fluctuate and decline over time, while the average values of 13 of the remaining 18 positive indicators fluctuate or continue to rise, and the average values of another five indicators fluctuate or continue to decline. For example, the mean value of the tertiary sector showed a continuous upward trend, $37.27 \%$ in $2014,42.58 \%$ in 2016 , and $44.17 \%$ in 2018 . The residential living area per capita was 33.8 square meters/person in 2014, declined to 31.78 square meters/ person in 2016, and rebounded to 32.09 square meters/ person in 2018. But it showed a fluctuating downward trend from the overall perspective. In a word, the majority of indicators showed upward trend over time, and some declining indicators showed a slightly downward trend. 


\section{Results and Discussion}

Based on the above study, development index of the ecological environment, economic growth and residential environment in the Yellow River Basin and the coupling coordination among the three systems from 2014 to 2018 were obtained. The Yellow River basin was divided into three parts, the upper, middle and lower reaches to compare the variability among them and the whole Yellow River basin for a clearer analysis.

Analysis of the Characteristics of the Eco-Environmental Development Index

As shown in Fig. 2, the overall ecological environment in the Yellow River basin develops with minor fluctuation. The ecological environment development index was 0.642 in 2014 and 0.633 in 2018, which was basically stable. In the process of ecological environment development from 2014 to 2018, the development of the upper reaches of the Yellow River was better than that of its lower reaches, which is better than that of the middle reaches. Especially after 2015 the ecological environment of the upper reaches of the Yellow River was significantly better than that of the lower reaches and the middle reaches. The ecological environment index of the upper reaches of the Yellow River has fluctuated and increased over time, thanks to the emphasis on ecological environment and increased investment in environmental management, etc. Although there was a decline in 2017, it still remained above 0.6, maintaining a high level of development. The development trend of the middle reaches of the Yellow River was in a "U" curve, reaching a low point in 2016 with a development index of 0.46. After 2016, the trend has been on the rise. This indicated that the ecological environment of the middle reaches of the Yellow River previously was sacrificed for the sake of economic or other development, and after the development of other aspects became effective, the attention to the environment increased. Therefore, according to the development trend, it can be predicted that the ecological environment development index of the middle reaches of the Yellow River will grow in the coming years. The ecological environment index of the lower reaches of the Yellow River showed a significant decline, from 0.55 in 2014 to a low point of 0.458 in 2017. And although it rebounded in 2018, the range was small, only increasing by 0.015 , which showed that the attention paid to the ecological environment of lower reaches of the Yellow River decreased. Hence, the ecological environmental protection and environmental management should be considered as a priority in the subsequent development.

\section{Economic Development Index Characteristics Analysis}

As shown in Fig. 3, the economic index of the Yellow River basin showed an upward trend in general with some fluctuations, with an economic index of 0.35 in 2014 and growing to 0.37 in 2018. However, the overall economic development of the Yellow River basin is not as good as that of the upper, middle and lower reaches, and the overall economic development of the Yellow River basin is not well-developed, with the highest economic development index of only 0.436 in the upper reaches of the Yellow River in 2018. Before 2016 (including 2016), the economic development of the lower reaches of the Yellow River was better than that of its middle reaches, which was better than that of the upper reaches. However, after 2016, the upper reaches of the Yellow River experienced rapid economic growth and replaced the lower reaches as the best developed region within the Yellow River basin. The economic development index of the upper reaches of the Yellow River was 0.377 in 2014, and rose to 0.436 in 2018,

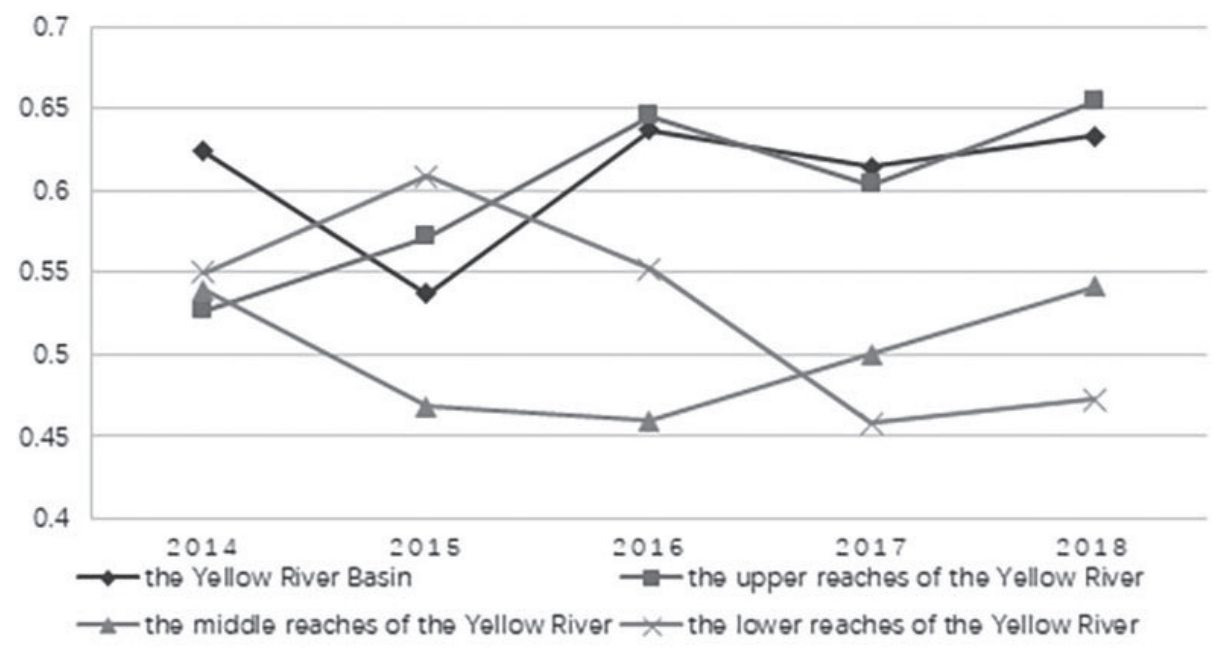

Fig. 2. Trend of the Eco-environmental Development Index in the Yellow River Basin from 2014 to 2018. 


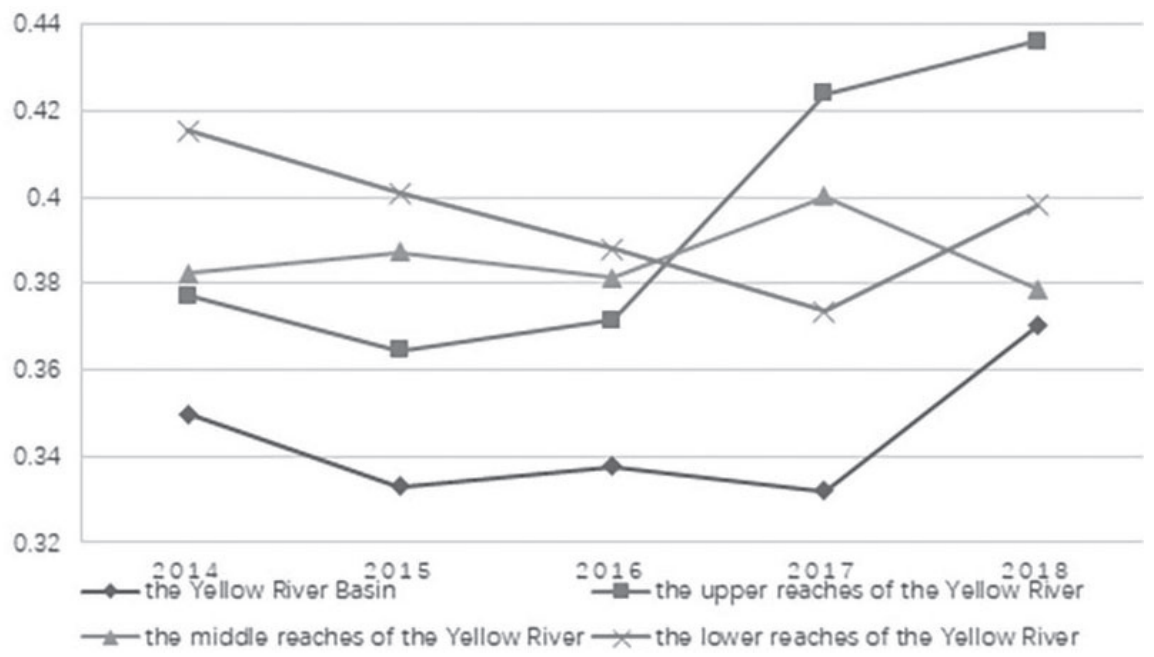

Fig. 3. Trend of Economic Development Index in the Yellow River Basin from 2014 to 2018.

featuring an obvious increase. This is because the economic development has expanded beyond the eastern coastal areas and the eastern development could drive the western development. The economic development of the middle reaches of the Yellow River region showed fluctuations almost the same as what it was before, with a maximum value of 0.4 (2017) and a minimum value of 0.379 (2018), with a fluctuation range of only about 0.02 , which showed that the economic development of the middle reaches is relatively stable. However, there was a downward trend after 2017. Hence, it is necessary to seize the opportunity of high-quality development of the Yellow River basin to improve the economic development. There was a drop in the development of lower reaches from 2014 to 2017, decreasing from 0.415 in 2014 to 0.374 in 2017. The decline was obvious due to the fact that China's economic growth has shifted from high-speed development to medium speed development in recent years, and the proportion of secondary industry and GDP per capita have decreased.
As China's economic development enters a new stage and the quality of development is gradually improved, the economic development index of the lower reaches will increase after it gradually adapts to the shift from high speed to high quality economic development. It is a promising indication that the economic development index increased in 2018 compared with 2017.

\section{Analysis of Residential Environment Development Index Characteristics}

As shown in Fig. 4, the residential environment development index of the Yellow River basin showed fluctuations and almost the same as the what it was before, with the residential environment development index of 0.497 in 2014, increasing to 0.526 in 2015, then decreasing to 0.468 in 2017 , and returning to 0.5 in 2018. This showed that the residential environment development index fluctuated around 0.5 from 2014 to 2018. In 2014, there was a significant difference in

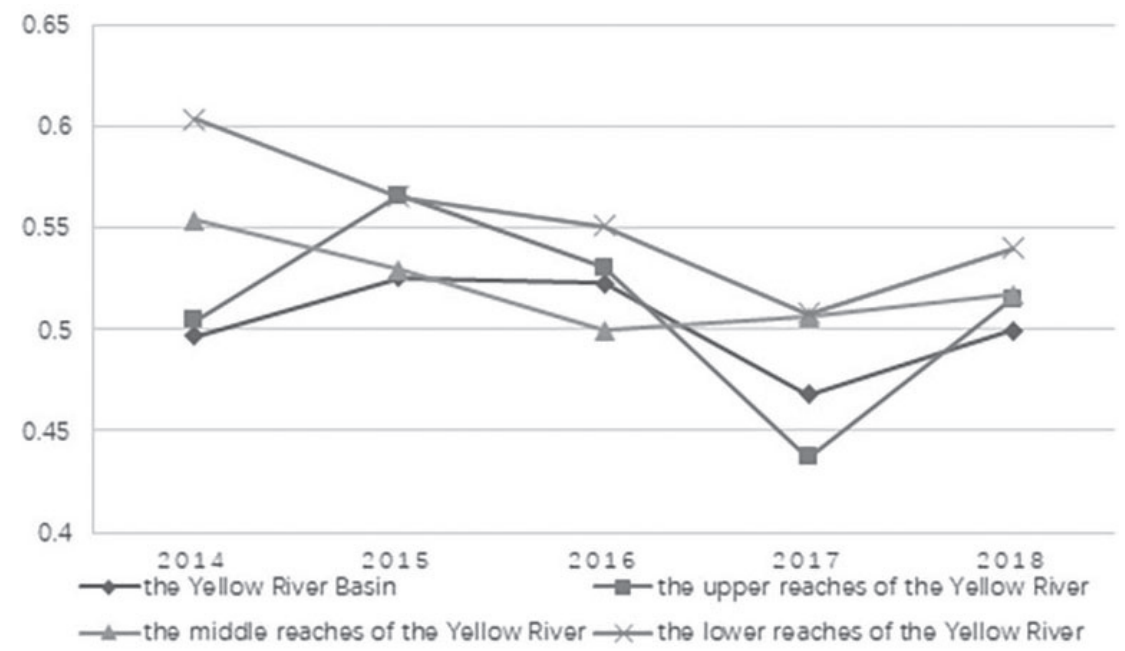

Fig. 4. The Residential Environment Development Index Trend in The Yellow River Basin from 2014 to 2018. 
the residential environment development index among the upper, middle and lower reaches of the Yellow River basin, and the difference gradually narrowed after 2018 , with the maximum difference being only 0.015 . The trend in the upper reaches is similar to the overall trend in the Yellow River basin, both rising to the highest point in 2015, falling to the lowest point in 2017, and returning to the average level in 2018, fluctuating around 0.5 . The middle reaches and the lower reaches showed a fluctuating downward trend in the residential environment index, the residential environment index in the middle reaches declining from 0.554 in 2014 to 0.499 in 2016 and rebounding to 0.517 in 2018; while that in lower reaches declined from 0.604 in 2014 to 0.508 in 2017 and rebounded to 0.54 in 2018. This is due to the rapid population growth in the middle and lower reaches of the Yellow River, and infrastructure such as education and medical care cannot keep up with such rapid population growth, resulting in the continuous decline of the residential environment index. Therefore, while managing the ecological environment and developing the economy, the construction of infrastructure should be strengthened.

\section{Analysis on the Coupled Coordination of the Three Systems}

As shown in Table 4 and Fig. 5, the overall coupling coordination of ecological environment, economic development and residential environment in the Yellow River basin fluctuated and increased over time with a high coordination, with a coupling coordination of
0.699 in 2018 , which was only 0.001 lower than that of the intermediate coordination. The upper reaches of the Yellow River were the region with the largest increase in coupling coordination growing from 0.681 in 2014 to 0.726 in 2018 , upgrading from primary coordination to intermediate coordination. This was due to not only the economic development of the upper reaches of the Yellow River, but also the increasing attention to the ecological environment and living environment. The coupling coordination in the middle reaches of the Yellow River showed fluctuation and almost kept the same as what it was before, but it was lower than that of the Yellow River basin as a whole, reaching the lowest point of 0.666 in 2016. The coupling coordination in the lower reaches of the Yellow River declined continuously from 2014 to 2017, reducing from 0.719 in 2014 to 0.665 in 2017, and rebounded to 0.683 in 2018, from intermediate coordination down to primary coordination. In a word, the coupling coordination of the Yellow River Basin has not improved significantly during the five years from 2014 to 2018, all being in the primary and intermediate coordination development. If we are to further improve the coupling coordination of the Yellow River Basin, we should focus on improving the growth of backward areas.

Although the overall and intra-basin coordination of the Yellow River basin is relatively well developed, the economic development is obviously lagging behind the ecological and residential environments. In order to improve the coupling coordination, it is necessary to make the development of the three systems coordinated. Hence, the high-quality economic development of

Table 4. Evaluation the coupled coordination among ecological environment, economic development and residential environment in the Yellow River Basin from 2014 to 2018.

\begin{tabular}{|c|c|c|c|c|c|c|c|}
\hline Region & Year & $f(x)$ & $\mathrm{g}(\mathrm{y})$ & $\mathrm{h}(\mathrm{z})$ & $\mathrm{D}$ & $\mathrm{C}$ & Coupling coordination level \\
\hline \multirow{5}{*}{$\begin{array}{c}\text { Yellow } \\
\text { river } \\
\text { basin }\end{array}$} & 2014 & 0.624 & 0.350 & 0.497 & 0.691 & 0.973 & $\begin{array}{l}\text { Primary delay for the coordination of economic } \\
\text { development }\end{array}$ \\
\hline & 2015 & 0.537 & 0.333 & 0.526 & 0.674 & 0.977 & $\begin{array}{l}\text { Primary delay for the coordination of economic } \\
\text { development }\end{array}$ \\
\hline & 2016 & 0.637 & 0.338 & 0.523 & 0.695 & 0.967 & $\begin{array}{l}\text { Primary delay for the coordination of economic } \\
\text { development }\end{array}$ \\
\hline & 2017 & 0.614 & 0.332 & 0.468 & 0.676 & 0.969 & $\begin{array}{l}\text { Primary delay for the coordination of economic } \\
\text { development }\end{array}$ \\
\hline & 2018 & 0.633 & 0.370 & 0.500 & 0.699 & 0.977 & $\begin{array}{l}\text { Primary delay for the coordination of economic } \\
\text { development }\end{array}$ \\
\hline \multirow{5}{*}{$\begin{array}{l}\text { Upper } \\
\text { Reaches }\end{array}$} & 2014 & 0.527 & 0.377 & 0.504 & 0.681 & 0.989 & $\begin{array}{l}\text { Primary delay for the coordination of economic } \\
\text { development }\end{array}$ \\
\hline & 2015 & 0.572 & 0.364 & 0.566 & 0.700 & 0.979 & $\begin{array}{l}\text { Intermediate delay for the coordination of } \\
\text { economic development }\end{array}$ \\
\hline & 2016 & 0.645 & 0.372 & 0.531 & 0.709 & 0.975 & $\begin{array}{l}\text { Intermediate delay for the coordination of } \\
\text { economic development }\end{array}$ \\
\hline & 2017 & 0.604 & 0.424 & 0.437 & 0.694 & 0.987 & $\begin{array}{l}\text { Primary delay for the coordination of economic } \\
\text { development }\end{array}$ \\
\hline & 2018 & 0.654 & 0.436 & 0.515 & 0.726 & 0.986 & $\begin{array}{l}\text { Intermediate delay for the coordination of } \\
\text { economic development }\end{array}$ \\
\hline
\end{tabular}


Table 4. Continued.

\begin{tabular}{|c|c|c|c|c|c|c|c|}
\hline Region & Year & $f(x)$ & $\mathrm{g}(\mathrm{y})$ & $h(z)$ & $\mathrm{D}$ & $\mathrm{C}$ & Coupling coordination level \\
\hline \multirow{5}{*}{$\begin{array}{l}\text { Middle } \\
\text { Reaches }\end{array}$} & 2014 & 0.539 & 0.382 & 0.554 & 0.696 & 0.986 & $\begin{array}{l}\text { Primary delay for the coordination of economic } \\
\text { development }\end{array}$ \\
\hline & 2015 & 0.468 & 0.387 & 0.53 & 0.677 & 0.992 & $\begin{array}{l}\text { Primary delay for the coordination of economic } \\
\text { development }\end{array}$ \\
\hline & 2016 & 0.46 & 0.381 & 0.499 & 0.666 & 0.994 & $\begin{array}{l}\text { Primary delay for the coordination of economic } \\
\text { development }\end{array}$ \\
\hline & 2017 & 0.5 & 0.4 & 0.506 & 0.683 & 0.994 & $\begin{array}{l}\text { Primary delay for the coordination of economic } \\
\text { development }\end{array}$ \\
\hline & 2018 & 0.542 & 0.379 & 0.517 & 0.688 & 0.988 & $\begin{array}{l}\text { Primary delay for the coordination of economic } \\
\text { development }\end{array}$ \\
\hline \multirow{5}{*}{$\begin{array}{l}\text { Lower } \\
\text { Reaches }\end{array}$} & 2014 & 0.55 & 0.415 & 0.604 & 0.719 & 0.988 & $\begin{array}{l}\text { Intermediate delay for the coordination of } \\
\text { economic development }\end{array}$ \\
\hline & 2015 & 0.608 & 0.401 & 0.565 & 0.719 & 0.984 & $\begin{array}{l}\text { Intermediate delay for the coordination of } \\
\text { economic development }\end{array}$ \\
\hline & 2016 & 0.552 & 0.388 & 0.551 & 0.7 & 0.987 & $\begin{array}{l}\text { Intermediate delay for the coordination of } \\
\text { economic development }\end{array}$ \\
\hline & 2017 & 0.458 & 0.374 & 0.508 & 0.665 & 0.992 & $\begin{array}{l}\text { Primary delay for the coordination of economic } \\
\text { development }\end{array}$ \\
\hline & 2018 & 0.473 & 0.398 & 0.54 & 0.683 & 0.992 & $\begin{array}{c}\text { Primary delay for the coordination of economic } \\
\text { development }\end{array}$ \\
\hline
\end{tabular}

the Yellow River basin is essential. As the economy of upper reaches of Yellow River basin continues to develop, and the ecological environment is gradually improving. Therefore, in order to improve the coupling coordination of the upper reaches of the Yellow River, it is necessary to ensure better residential environment for people and increase the investment on construction of infrastructure on the basis of maintaining continuous economic development and sound ecological environment. The trend of coupling coordination in the middle reaches of the Yellow River shows the same "U" shape as that of ecological environment and residential environment, so it can be predicted that the coupling coordination there will continue to rise in the future. However, in the lower reaches of the Yellow River, the coupling coordination falls from intermediate level to primary level. In general, in order to improve the coupling coordination, it is necessary to optimize the

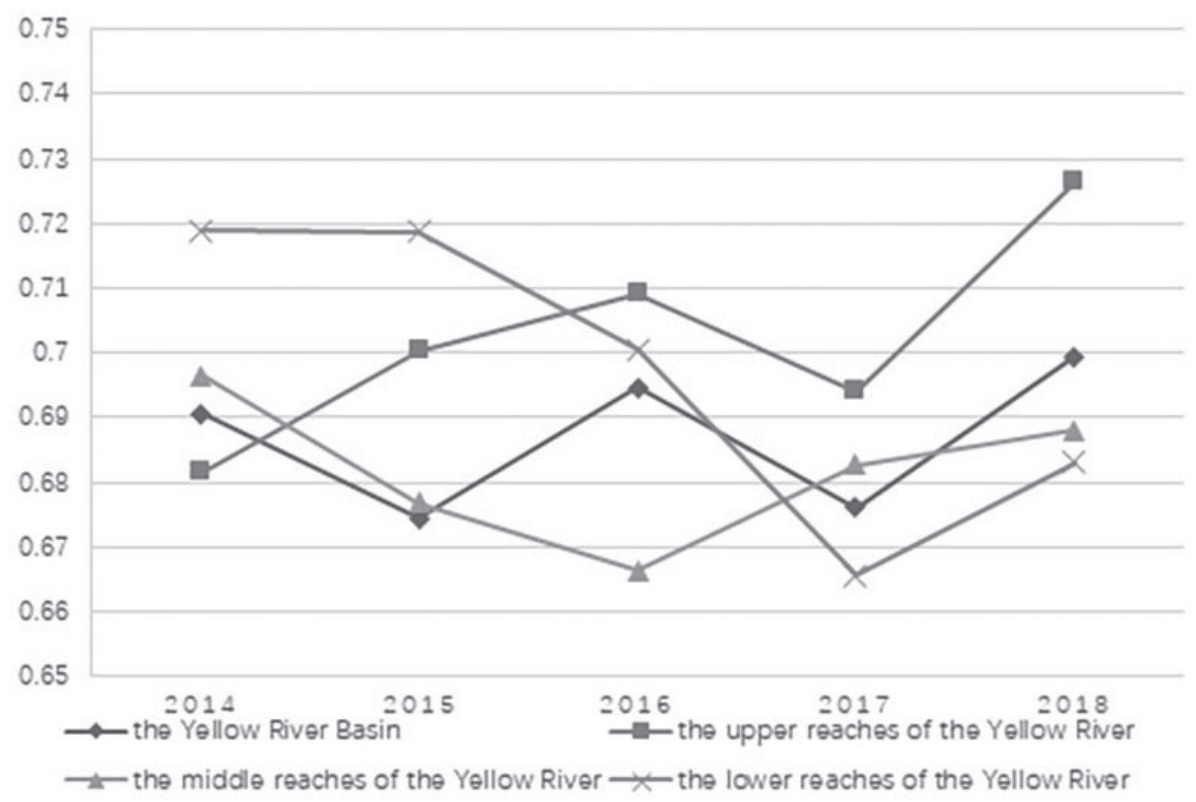

Fig. 5. Coupling coordination among ecological environment, economic development and residential environment in the Yellow River Basin from 2014 to 2018. 
economic structure, improve the quality of economic development, and take reasonable measures to promote the integration and coordination among economic growth, ecological environment and residential environment.

\section{Discussion}

Based on the above research content, the proposed discussion are as follows.

Seize the opportunity of ecological protection and high-quality development in the Yellow River Basin to promote joint regional development. Although the high-quality development in the Yellow River Basin has made certain achievements, the quality needs to be improved and the gap among regions needs to be narrowed urgently. It is imperative to take advantage of city clusters for the resource integration, such as the Shandong Peninsula City Cluster with Jinan and Qingdao as the dual core, the Middle China City Cluster with Zhengzhou as the center, the Guan Zhong Plain City Cluster with Xi'an as the center, the Central Shanxi City Cluster with Taiyuan as the core, the Hohhot-Baotou-Ordos-Yulin City Cluster with Hohhot as the center, the Ningxia City Cluster along the Yellow River with Yinchuan as the core, and the LanzhouXining City Cluster with Lanzhou and Xining as the dual core in the Yellow River Basin, contributing to the expansion from cities to city clusters and to the whole basin. Besides, the upper, middle and lower reaches should be promoted to become an open region, realizing regional aggregation and effective allocation and efficient utilization of resources, what's more, the coupling coordination of ecological environment, economic development and residential environment in the Yellow River basin should also be improved, eventually contributing to the high-quality development of the Yellow River basin.

Achieve differentiated regional development according to local conditions. The three regions of the upper, middle and lower reaches of the Yellow River Basin are endowed with different resources characterized by regional distinction and significant development differences. Therefore, we should encourage the implementation of differentiated development strategies based on local conditions. Let the well-developed regions to drive the backward regions. The leading regions and cities should play the driving and leading roles with a highly coupling coordination demonstration. Relying on the characteristics of local industries and development, each region follows the development path of "harmony in diversity". The upper area of the Yellow River will transform the advantages of ecological and environmental resources into advantages of economic development and residential environment, leverage all resources, and develop industries with local characteristics and residential environment with unique characteristics. The densely populated middle area of the Yellow River should expand industries, increase the added value of the secondary and tertiary industries, develop emerging industries and eliminate outdated production capacity. And it can take the path of green industry and residence and realize the sustainable development among ecological environment, economic environment and residential environment. The lower reaches of the Yellow River are a key region in China when it comes to dense population and economic development. The economic growth cannot be achieved at the expense of the environment, so it is necessary to coordinate the relationship between regional ecological environment and new industrialization, and between the residential environment and urbanization.

Enhance the sustainable development of the Yellow River Basin with the ecological protection as the priority. The Yellow River basin is ecologically fragile If we are to achieve the coordinated development of ecological environment, economic development and residential environment, and to realize the high-quality development of the Yellow River basin, we should put ecological protection in the first place. The upper area should focus on improving water conservation capacity. The midstream area should focus on soil and water conservation and pollution source management, and the downstream area should focus on protecting wetland ecosystems and biodiversity. Developing an eco-friendly economy is indispensable with the protection as the fundamental. The government should play an active role in financial guiding to increase environmental protection expenditure and investment in the environment as a way to put more investments on eco-friendly and new energy enterprises, further develop the green industrial system, continuously improve the coordination between ecological environment and economic development, and establish a green and favorable residential environment.

\section{Conclusion}

By constructing the evaluation index system of ecological environment, economic development and residential environment and analyzing the coupling coordination relationship and changing law of the three kinds of environment in the Yellow River Basin by using entropy and coupling coordination degree model, the following four conclusions have been drawn on the basis of the evaluation index system of ecological environment, economic development and residential environment and analysis on the coupling coordination and laws among these three aspects.

In terms of ecological environment, the Yellow River basin as a whole showed an upward trend from 2014 to 2018. And the development index was fluctuating and stable, all were higher than 0.6 in all years except for 2015. The development index of the upper reaches of the Yellow River area fluctuated and rose over time, and the development was slightly better than that of the middle and lower reaches. The development index 
of the middle reaches of the Yellow River area was in a "U" shape, so it could be predicted that the future $t$ is getting increasingly better. The development index of the lower reaches of the Yellow River had a significant decreasing trend, so we should pay extra attention to the protection and optimization of the ecological environment in the future.

The overall economy of the Yellow River basin was relatively backward during 2014 2018, and the development index was fluctuating, rising from 0.35 to 0.37 , with a small increase. The economic development index of the upper reaches of the Yellow River has increased by 0.59 during 5 years, with a large increase. The economic development of its middle reaches was more stable, and the development index fluctuated within 0.02. The economic development index of its lower reaches continued to decline between 2014 and 2017 but rebounded in 2018 .

In terms of residential environment, the overall development of the Yellow River basin from 2014 to 2018was almost the same as what it was before, with the development index fluctuating up and down around 0.5. During the five years, the gap among the upper, middle and lower reaches of the Yellow River has narrowed significantly. The development trend of the upper reaches of the Yellow River was similar to that of the whole Yellow River basin, fluctuating up and down around 0.5. The development of the middle and lower reaches of the Yellow River showed a fluctuating downward trend.

In terms of the coupling coordination of the three systems, the coupling coordination in the Yellow River basin showed a "W" pattern from 2014 to 2018, and the coupling coordination was at primary coordination, which was only 0.001 lower than that of the intermediate coordination. The coupling coordination in the upper reaches of the Yellow River region raised rapidly during 5 years, from primary coordination to intermediate coordination. The coupling coordination in the middle reaches of the Yellow River region was stable in the primary coordination. The coupling coordination in the lower reaches of the Yellow River was decreasing from intermediate coordination to primary coordination.

\section{Acknowledgment}

Many people have offered me valuable help in this paper, especially my tutor, who helped me complete a series of work such as revising the content of the article and checking the format. This study was supported by the National Natural Science Foundation of China (Grant No. 71573019).

\section{Conflicts of Interest}

The authors declare no conflict of interest.

\section{References}

1. ZHANG Y., HUANG S., CHEN X., GUO X. L., FENG, W., LIU Y., PANG M., FANG Y. Suitability of Human Settlement Environment in Buyei Traditional Villages in Rocky Desertification Area of Guizhou, China. Chinese Journal of Applied Ecology. 30 (09), 3203-, 2019.

2. ZHU J., TIAN S., TAN K., DU P. Human Settlement Analysis Based on Multi-temporal Remote Sensing Data: A Case Study of Xuzhou City, China. Chinese Geographical Science. 26 (03), 389, 2016.

3. XUE Q., YANG X. Evaluation of The Suitability of Human Settlement Environment in Shanghai City Based on Fuzzy Cluster Analysis. Thermal Science. 24 (04), 2543, 2020.

4. GROSSMAN G., KRUEGER A. Environmental Impacts of a North American Free Trade Agreement. National Bureau of Economic Research Working Paper, No. 3914 (3914), 1, 1991

5. ALAM R., ADIL M.H. Validating the Environmental Kuznets Curve in India: Ardl Bounds Testing Framework. OPEC Energy Review. 43 (03), 277, 2019

6. BELLO M., SOLARIN S., YUEN Y. The Impact of Electricity Consumption on $\mathrm{CO}_{2}$ Emission, Carbon Footprint, Water Footprint and Ecological Footprint: The Role of Hydropower in An Emerging Economy. Journal of Environmental Management. 219 (01), 2018.

7. GILL F., GILL A., VISWANATHAN K., KARIM M. Analysis of Pollution Haven Hypothesis (PHH) and Environmental Kuznets Curve (EKC) in Selected Association of South-East Asian Nations (ASEAN) Countries. Review of Economics and Development Studies. 6 (01), 83, 2020.

8. LI S., SHI J., WU Q. Environmental Kuznets Curve: Empirical Relationship between Energy Consumption and Economic Growth in Upper-Middle-Income Regions of China. International Journal of Environmental Research and Public Health. 17 (19), 69, 2020.

9. URGILES-SANCHEZ C. Is There an Inverted U-Shaped Curve? Empirical Analysis of The Environmental Kuznets Curve in Singapore*. Asia-Pacific Journal of Accounting \& Economics. 2018.

10. SHEN Z. Coordinated Environment and Economy in Coastal Development Based on Industrial Wastewater and SO2 Emissions. Journal of Coastal Research. 109 (sp1), 2020.

11. ZHANG H., ZHU Z., FAN Y. The Impact of Environmental Regulation on The Coordinated Development of Environment and Economy in China. Natural Hazards. 91 (02), 473, 2018.

12. LI W., YI P., ZHANG D., ZHOU Y. Assessment of Coordinated Development Between Social Economy and Ecological Environment: Case Study of Resource-Based Cities in Northeastern China. Sustainable Cities and Society. 59, 102208, 2020.

13. LIU P. Marine Ecological Construction and Economic Coordination in Beibu Gulf City Cluster of China. Journal of Coastal Research. 109 (sp1), 2020.

14. SHARMA S. Knowing the Linkages Between Poverty and Environment from Village Economy of Bihar. International journal of environment and development. 14 (02), 207,2017.

15. WANG C., WANG R. Study on The Coupling and Coordinated Development of Tourism Economy and Ecological Environment in Guilin City. IOP Conference Series: Earth and Environmental Science. 546 (03), 032020 (6pp), 2020. 
16. ZHAO X., LIU Z., ZHAO H. Study on the Mechanism of Economic Development and Eco-environment Coupling in Mountainous Counties - Taking Pingshan County of Hebei Province as an Example. Research of Soil and Water Conservation. 21 (03), 176, 2014.

17. CAO Y., GUO K., ZHANG Q., LI X. The Evolutionary Characteristics of the Coupling Relationship of Energy, Economy and Environment in Hebei Province, China. IOP Conference Series: Earth and Environmental Science. 558 (04), 042021 (8pp), 2020.

18. LI S.M., SHI P.J. Coordinated Development between Agricultural Economy and Ecological Environment in Huangshui River Basin in Qinghai Province. $20176^{\text {th }}$ International Conference on Energy and Environmental Protection (ICEEP 2017). 2017.

19. WANG D. Evaluation on Coupling and Coordinated Development of Tourism, Economy and Environment in Yining City, Xinjiang. Proceedings of 2017 International Conference on Humanities Science, Management and Education Technology (HSMET 2017), 5, 2017.

20. XU M., CHEN C., DENG X. Systematic analysis of the coordination degree of China's economy-ecological environment system and its influencing factor. Environmental Science and Pollution Research. 26 (29), 29722, 2019.

21. ZHAO L., FAN X. Assessment of The Relationship Between the Economy and The Environment Based on
Ecosystem Services Value in Nanping City, China. Applied Ecology and Environmental Research. 16 (06), 8029, 2018.

22. ZHANG H., LI T., CHEN Y. Dynamic Comprehensive Evaluation of Ecological Environment of 12 Provinces and Cities in Western China. The Journal of Risk Analysis and Crisis Response. 9 (03), 2019.

23. ZHU Z., WANG L., LUO L. Analysis of the Coordination Development of Economy and Environment Public Services in the Yangtze River Economic Zone. Environmental Protection Science. 44 (01), 36, 2018.

24. SHAO B., CHEN X. Research on the actuality of the coordinated development of economy and ecological environment in northwest China. China Forestry Economics. (01), 136-141, 2005.

25. YANG X., ZHANG D., JIA Q., ZHANG W., WANG T. Exploring the Dynamic Coupling Relationship between Agricultural Economy and Agro-Ecological Environment in Semi-Arid Areas: A Case Study of Yulin, China. Sustainability. 11 (08), 2019.

26. ZHU H., TANG X. Study on Coordinated Development of Ecological Environment and Economy in Seven Cities along the Yangtze River Basin. China Forestry Economics. (04), 9, 2019.

27. CHEN X., JIN B. Key Points of High-quality Development in the Yellow River Basin. Reform. No. 309 (11), 25, 2019. 